\title{
JORNAL NA ESCOLA: CONHECIMENTO E AUTO-ESTIMA
}

\section{Crianças da quarta série do ensino fundamental produzem Jornal da classe e Jornal da cana-de-açúcar em projeto pedagógico multidisciplinar}

O objetivo do projeto pedagógico desenvolvido com os alunos da quarta série da Escola Estadual Bento Carlos Botelho do Amaral foi o de transformar a sala de aula num ambiente de trabalho agradável, permitindo aos alunos produzirem informações, valorizando seus conhecimentos diante da comunidade. Para desenvolver estes objetivos trabalhamos com jornais, revistas e textos informativos.

Do ponto de vista programático, estabelecemos como fundamental levá-los a:

- desenvolver a habilidade da comunicação e expressão escrita e oral;

- utilizar diferentes registros dos conteúdos trabalhados em sala de aula e extra-classe;

- valorizar o trabalho em grupo, tornando-os capazes de ação crítica e cooperativa para a construção coletiva do conhecimento;

- utilizar as diferentes linguagens - verbal, gráfica, plástica - como meio para produzir, expressar e comunicar idéias;

- despertar hábitos de estudo, de ordem e clareza no desenvolvimento do trabalho;

- construir conhecimentos, desenvolvendo a auto-estima, facilitando a aquisição do aprendizado;

- contribuir para a formação de uma pessoa crítica e com habilidades para o exercício da cidadania;

- fixar e enriquecer a aprendizagem, despertando no aluno o interesse pela confecção do jornal, fonte permanente de consultas;

- utilizar a pesquisa e coleta de informações para produzir e ampliar seus conhecimentos iniciados na sala de aula.

Iniciamos o trabalho fazendo leitura, manuseando e explorando

\section{A AUTORA}

Izilda Bueno Barrios Campanhão

Professora no ensino fundamental na Escola Estadual Bento Carlos Botelho do Amaral, Guariba - São Paulo. jornais, gibis e revistas adquiridas pela escola, recebidas como doações feitas pela comunidade e pelos alunos. Através de observação sobre o interesse dos alunos por determinados 
assuntos, selecionamos o material a ser utilizado durante as aulas. $\mathrm{O}$ material foi selecionado, procurando incentivá-los, propondo a produção de um jornal da classe. A sugestão foi aceita e todos se propuseram a colaborar. A produção do nosso jornal obedeceu às seguines etapas: - escolha dos temas e discussão sobre o material necessário e formas de o fazer; - produção dos textos e dos desenhos;

- seleção dos textos e desenhos utilizados;

- colagem dos textos e desenhos nas páginas do jornal;

- montagem, finalização das páginas e confecção da capa.

Normalmente utilizamos folhas de papel pardo para confeccionar o jornal, pois são folhas grandes, rústicas e resistentes. O número de páginas depende da quantidade de material produzido.

Os temas, ilustrações e confecção das atividades são de autoria dos alunos. A produção do jornal é manual e todas as etapas de produção recebem a minha orientação.

Além do jornal da classe, propusemos a realização de um outro jornalzinho: Jornal da cana. Para desenvolver as atividades do Jornal da cana, realizamos uma visita à Usina São Martinho, em Pradópolis (SP), com o objetivo de conhecer o processo de fabricação do açúcar e do álcool, produtos extraídos da cana-de-açúcar, importante recurso natural renovável disponível na nossa região e principal atividade econômica da cidade de Guariba-SP.

Mostramos aos alunos os subprodutos resultantes da fabricação do açúcar e do álcool e a sua utilização econômica. O bagaço da cana, por exemplo, é utilizado para a alimentação animal, co-geração de energia elétrica, bem como para vinhaça e fertilizantes.

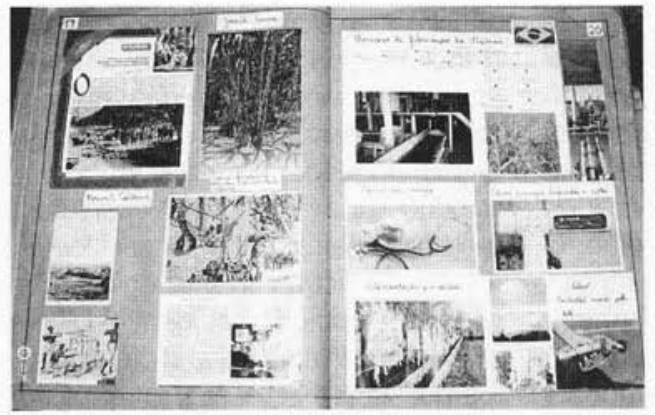

Tivemos a oportunidade também de proporcionar aos alunos conhecer a empresa na qual alguns pais trabalham, favorecendo a integração da família com a empresa. As atividades do jornal foram desen- 
volvidas paralelamente ao trabalho realizado na sala de aula. O conteúdo acabou sendo bem variado, com temas multidisciplinares. Os alunos participaram com interesse e espontaneidade, trazendo sugestões e materiais, contribuindo para a qualidade da produção do jornal.

\section{INTEGRAÇÃO E AUTO-ESTIMA}

Antes de efetuar esta experiência com o jornal, os alunos tinham pouco contato com jornais, revistas e textos diversos. Tinham dificuldade para manusear jornais e localizar assuntos. Não sentiam motivação para pesquisar, ampliar e produzir informações. Os textos produzidos na sala de aula eram limitados, sem muita criatividade e pouco atrativos.

Percebemos que na escola o jornalzinho foi bem aceito. Despertou nos alunos o interesse pela leitura e produção de textos, estimulando o aprendizado, a criatividade e a participação nos trabalhos.

Como professora posso dizer que desenvolver o jornalzinho é muito gratificante, pois através dele o conhecimento é desenvolvido e adquirido. Os alunos tornam-se mais espertos e observadores, desvinculados da aprendizagem pronta e formal; e propõem-se a construir o seu próprio conhecimento. Adotei a prática da experiência por considerar ser um método eficiente de ensinar e aprender.

Nos primeiros trabalhos as dificuldades são maiores, mas logo são superadas mediante os resultados obtidos. $\mathrm{O}$ jornalzinho circula por toda a escola tornando os alunos conhecidos e valorizados, promovendo a auto-estima, necessária no processo de aprendizagem.

A colaboração da família do aluno, da comunidade e da direção da escola foi fundamental na realização e conclusão dos trabalhos com resultados positivos.

Resumo: Professora do ensino fundamental, da região do Vale do Ribeira em São Paulo, relata experiência com alunos da quarta série que, a partir do manuseio de jornais, pesquisa e exercício com as linguagens verbal (informativa), gráfica e plástica, produziram o Jornal da classe e o Jornal da cana, principal atividade econômica da região. 0 trabalho multidisciplinar contribuiu para que os alunos se envolvessem com a construção do conhecimento de maneira alegre e criativa. Os resultados demonstraram o bom aproveiramento dos alunos e a elevação de sua alto-estima.

Palavras-chave: jornal, comunicação e expressão, auto-estima, ensino fundamental
Abstract: An elementary school teacher, from the Vale do Ribeira region, in São Paulo, reports on an experience carried out with fourth-grade students, who, by manipulating newspapers, researching and exercising with verbal languages (informative), both graphic and plastic, produced the Classroom Newspaper (Jornal da classe) and the Sugarcane Newspaper (Jornal da cana), the main economic activity in the region. The multidisciplinary work contributed to student involvement with building knowledge in a happy and creative manner. The results demonstrate that the students profited well and that their self-esteem went up because of the project.

Key words: newspaper, communication and expression, self-esteem, elementary school 